\title{
PENGARUH METODE BRAINSTORMING TERHADAP PENGETAHUAN DAN SIKAP TENAGA KERJA BONGKAR MUAT TENTANG HIV DAN AIDS DI PELABUHAN GORONTALO
}

\author{
M. Ardan ${ }^{1}$, Muammar $^{2}$, Restu Yunus ${ }^{3}$, Fahri Guslan Haimin ${ }^{4}$ \\ ${ }^{1}$ STIKES Mutiara Mahakam Samarinda \\ ${ }^{2}$ Kantor Kesehatan Pelabuhan Gorontalo \\ ${ }^{3}$ STIKES Mutiara Mahakam Samarinda \\ ${ }^{4}$ STIKES Mutiara Mahakam Samarinda
}

Alamat korespondensi : (ardan0410@gmail.com/081256664436),

\begin{abstract}
ABSTRAK
Kasus HIV dan AIDS terus meningkat setiap tahun serta berpotensi terjadi peningkatan pada salah satu populasi kunci Tenaga Kerja Bongkar Muat (TKBM) dilingkungan pelabuhan sehingga diperlukan metode pendidikan kesehatan yang fokus terhadap promotif dan preventif untuk meningkatkan pengetahuan dan sikap. Penelitian ini bertujuan untuk mengetahui pengaruh metode brainstorming terhadap pengetahuan dan sikap TKBM tentang HIV dan AIDS di Pelabuhan Gorontalo. Penelitian ini menggunakan eskperimen semu dengan rancangan randomized pretest posttest design. Sampel diambil secara Purposive Sampling sebanyak 20 responden. Pengumpulan data menggunakan kuesioner dan wawancara. Data tidak terdistribusi normal sehingga menggunakan uji Wilcoxon. Hasil penelitian menunjukkan bahwa terjadi peningkatan pengetahuan $(28,50$ menjadi 43,05$)$ dan sikap $(30,70$ menjadi 43,80$)$. Hasil uji Wilcoxon menunjukkan ada perbedaan sebelum dan sesudah intervensi brainstorming terhadap Pengetahuan $(p=0,000)$ dan Sikap $(p=0,000)$ TKBM tentang HIV dan AIDS. Metode brainstorming menjadi pilihan dalam meningkatkan pengetahuan dan sikap sebagai upaya pencegahan primer, sehingga direkomendasikan menjadi program.
\end{abstract}

Kata Kunci : Sosialisasi, Brainstorming, Pengetahuan, Sikap, HIVIAIDS

\section{PENDAHULUAN}

AIDS dapat didefinisikan sebagai suatu sindrom atau kumpulan gejala penyakit dengan karakteristik defisiensi imun yang berat, dan merupakan manifestasi stadium akhir infeksi HIV. Acquired Immuno Deficiency Syndrome (AIDS) yang disebabkan oleh virus Human Immunodeficiency Virus (HIV), dimana virus ini menyerang sel-sel darah putih atau sistem kekebalan tubuh manusia, sehingga orang yang terserang penyakit ini tidak dapat melawan berbagai jenis penyakit yang menyerang tubuhnya (Desmon, 2015).

Dalam laporan situasi perkembangan HIV dan AIDS dan Infeksi Menular Seksual (IMS) Triwulan II Tahun 2018 Kemenkes RI, menyebutkan bahwa infeksi HIV di Indonesia ditemukan kasus infeksi HIV hingga Juli 2018 (301.959). Ini mengalami peningkatan dalam 3 tahun terakhir yakni pada tahun 2016 sebanyak 41.250 kasus dan meningkat pada tahun 2017 sebanyak 48.300 Kasus, laporan 12 Juli 2018 dilaporkan sudah mencapai angka 21.336. Sedangkan untuk AIDS hingga Juli 2018 dilaporkan sebanyak 108.829 kasus. Dalam 3 tahun terakihir cenderung fluktuatif menurun yakni 10.146 kasus pada 2016, dan pada tahun 2017 turun menjadi 9.280 kasus.
Per Juli 2018 sebanyak 6.162 kasus (Kemenkes RI, 2018).

Provinsi Gorontalo dari hasil rekapitulasi jumlah kasus HIV maupun AIDS angka kejadiannya mengalami peningkatan setiap tahunnya. Tahun 2016 prevalensi HIV $0,7 / 1.000$ penduduk yang meningkat pada Tahun 2017 menjadi 5,1/1.000 penduduk. Selanjutnya dilaporkan sampai pada bulan Juli 2018 sudah mencapai 9 kasus. Sedangkan untuk AIDS Pada Tahun 2016 terdapat $3,7 / 1.000$ penduduk dan meningkat pada tahun 2017 menjadi 6,1/1.000 penduduk. Adapun dilaporkan sudah sebanyak 30 kasus sampai dengan bulan Juli 2018 (Kemenkes RI, 2018). HIV merupakan penyakit yang menyerang kekebalan tubuh dengan perilaku seksual sebagai transmisi utama penularannya, terutama perilaku seksual pada kelompok risiko. TKBM (Tenaga Kerja Bongkar Muat) merupakan salah satu kelompok pria berisiko tinggi berdasarkan pendekatan pekerjaan menurut Survei Terpadu Biologis dan Perilaku.

Adapun survei di Pelabuhan Kalimas Surabaya dilakukan untuk mengetahui hubungan antara karakteristik, pengetahuan, dan sikap TKBM dengan perilaku seksual 
berisiko penularan HIV. Menurut data Survei Terpadu Biologis dan Perilaku kelompok populasi berisiko penularan HIV adalah wanita pekerja seks langsung maupun tidak langsung, penasun, waria, LSL, remaja dan pria berisiko diantaranya ojek motor, supir angkutan umum, Anak Buah Kapal, Buruh dan Tenaga Kerja Bongkar Muat (TKBM) di pelabuhan (Margawati \& Hargono, 2017). Pelabuhan merupakan kawasan yang berpotensi besar dalam penyebaran kasus HIV dan AIDS. Menurut survey pendahuluan dengan Lembaga Swadaya Masyarakat Kalandara yang menjalankan program pencegahan dan penanggulangan HIV dan AIDS di Pelabuhan Tanjung Emas Semarang tahun 2014, salah satu pekerja pelabuhan yang memiliki risiko tinggi terkena HIV dan AIDS yaitu tenaga kerja bongkar muat karena akses membeli jasa seks yang mudah, jam kerja yang teratur dan sistem pemberian upah harian. Selain itu didukung adanya akses transaksi seksual di sekitar pelabuhan yaitu tempat hiburan di area pelabuhan (Mardalina, 2015).

Berdasarkan latar belakang tersebut diatas, maka dipertimbangkan perlunya untuk dilakukan penelitian yang akan melihat pengaruh metode pendidikan kesehatan terhadap pengetahuan dan sikap Tenaga Kerja Bongkar Muat (TKBM) tentang HIIV dan AIDS Khususnya di Pelabuhan Gorontalo. Penelitian dengan metode fokus terkait promotif dan preventif ini dipilih untuk dilaksanakan, sehingga nantinya diharapkan dapat menjadi masukan dalam kegiatan penyampaian informasi khususnya ke masyarakat pelabuhan (salah satunya TKBM) dalam upaya untuk pencegahan transmisi utama penularan HIV dan AIDS pada kelompok berisiko di Pelabuhan Gorontalo.

\section{BAHAN DAN METODE}

Lokasi, Populasi, Sampel

Penelitian ini dilaksanakan di Pelabuhan Gorontalo, Provinsi Gorontalo pada tanggal 23 Maret s/d 09 Mei 2019. Populasi dalam penelitian ini adalah seluruh anggota TKBM di Pelabuhan Gorontalo. Sampel dalam penelitian ini sebanyak 20 orang dengan kriteria sebagai berikut :

1. Kriteria inklusi:
a. Anggota TKBM aktif di Pelabuhan Gorontalo
b. Berusia $>17$ tahun,
c. Dapat berkomunikasi dengan baik,
d. Dapat membaca dan menulis,
e. Bersedia menjadi responden.

2. Kriteria eksklusi:

TKBM yang positif HIV dan AIDS

\section{Pengumpulan Data}

1. Data primer diperoleh dari quisioner dan wawancara kepada anggota TKBM yang terpilih sebagai sampel dengan daftar pertanyaan yang telah disusun sebelumnya berdasarkan tujuan penelitian dan diisi sendiri oleh responden.

2. Data sekunder terkait TKBM yang diperoleh dari Kantor Syahbandar dan Otoristas Pelabuhan (KSOP) Gorontalo dan data dari Kantor Kesehatan Pelabuhan Kelas III Gorontalo

\section{Pengolahan Data}

1. Editing

Editing adalah tahapan kegiatan memeriksa validitas data yang masuk seperti memeriksa kelengkapan pengisian kuesioner, kejelasan jawaban, relevansi jawaban dan keseragaman suatu pengukuran.

2. Coding

Coding adalah tahapan kegiatan mengklasifikasi data dan jawaban menurut kategori masing-masing sehingga memudahkan dalam pengelompokan data.

3. Processing

Processing adalah tahapan kegiatan memproses data agar dapat dianalisis. Pemrosesan data dilakukan dengan cara memasukkan data hasil pengisian kuesioner ke dalam master tabel.

4. Cleaning

Cleaning yaitu tahapan kegiatan pengecekan kembali data yang sudah di masukkandan melakukan koreksi bila terdapat kesalahan.

\section{Analisis Data}

1. Analisis Univariat

Analisis univariat dilakukan untuk mendapatkan gambaran umum dengan cara mendeskripsikan setiap pertanyaan pengetahuan dan sikap yang digunakan dalam penelitian untuk melihat gambaran distribusi frekuensi.

2. Analisis Bivariat

Analisis bivariate dilakukan untuk menganalisis pengaruh antara variabel independen dan variabel dependen. Karena rancangan penelitian ini adalah menggunakan quasi eksperimen, maka digunakan komparasi dua sampel berpasangan. Analisis bivariat dilakukan untuk menganalisis pengaruh metode metode brainstorming terhadap peningkatan pengetahuan dan sikap TKBM Gorontalo tentang HIV dan AIDS, yaitu menggunakan uji wilcoxon dengan nilai alpha 5\%. Untuk melihat hasil kemaknaan 
perhitungan statistic digunakan batas kemaknaan 0,05.

\section{HASIL PENELITIAN}

1. Analisis Univariat

Tabel 1 Karakteristik Responden $(n=20)$

\begin{tabular}{|c|c|c|}
\hline Karakteristik & $\mathrm{n}$ & $\%$ \\
\hline Usia & & \\
$26-35$ tahun & 1 & 5 \\
$36-45$ tahun & 9 & 45 \\
$46-55$ tahun & 8 & 40 \\
$56-65$ tahun & 2 & 10 \\
\hline $\begin{array}{c}\text { Jenis Kelamin } \\
\text { Laki-Laki }\end{array}$ & 19 & 95 \\
Perempuan & 1 & 5 \\
\hline Status & 19 & 95 \\
Menikah & 19 & 5 \\
Belum Menikah & 1 & \\
\hline Pendidikan & 1 & 5 \\
Tidak Sekolah & 16 & 80 \\
SD & 3 & 15 \\
SMA & 19 & 95 \\
\hline Pendapatan & \\
<2 Juta & 1 & 5 \\
2 Juta & & \\
\hline \multicolumn{2}{|l}{} \\
\hline
\end{tabular}

Dari tabel 1 menunjukkan dari 20 responden lebih banyak responden yang berada pada rentang usia 36-45 tahun, yaitu sebanyak 9 orang (45\%), dan paling sedikit responden berusia $26-35$ tahun yaitu sebanyak 1 orang (5\%). Berdasarkan jenis kelamin yang paling banyak adalah berjenis kelamin laki-laki, yaitu dengan jumlah 19 orang (95\%), dan jenis kelamin perempuan yaitu berjumlah 1 orang $(5 \%)$. Berdasarkan status pernikahan Responden paling banyak status telah menikah yang berjumlah 19 orang (95\%) dan belum menikah 1 orang $(5 \%)$. Berdasarkan jenjang pendidikan responden paling banyak adalah berpendidikan SD sebanyak 16 orang $(80 \%)$, pendidikan SMA sebanyak 3 orang (15\%) dan paling sedikit tidak sekolah sebanyak 1 orang (5\%). Sedangkan pendapatan responden paling banyak lebih dari 2 juta perbulan sebanyak 19 orang $(95 \%)$ dan kurang dari 2 juta perbulan ada 1 orang $(5 \%)$.

2. Analisis Bivariat

Tabel 2 Perbedaan Pengetahuan dan Sikap Responden Sebelum dan Sesudah Intervensi Brainstorming.

\begin{tabular}{|c|c|c|c|}
\hline Hasil Statistik & Sebelum & Sesudah & $\begin{array}{c}\boldsymbol{p} \\
\text { value }\end{array}$ \\
\hline $\begin{array}{c}\text { Pengetahuan } \\
\text { Min - Max Mean } \\
\pm \text { SD }\end{array}$ & $\begin{array}{c}23-33 \\
28,5+3,0\end{array}$ & $\begin{array}{c}40-48 \\
43,0+1,7\end{array}$ & 0,000 \\
\hline $\begin{array}{c}\text { Sikap } \\
\text { Min - Max }\end{array}$ & $\begin{array}{c}25-34 \\
\text { Mean } \pm \text { SD }\end{array}$ & $\begin{array}{c}40,7+2,47 \\
40,8+1,4\end{array}$ & 0,000 \\
\hline
\end{tabular}

Tabel 2 menunjukkan bahwa nilai rata-ratadan standar deviasi skor pengetahuan sebelum dan sesudah intervensi sebesar $28,5+3,0$ menjadi $43,0+1,7$ dengan nilai $p$ value pengetahuan $0,000<0,05$ yang berarti ada perbedaan yang signifikan pengetahuan sebelum dan sesudah dilakukan intervensi brainstorming. Sedangkan rata-ratadan standar deviasi skor sikap sebelum dan sesudah intervensi sebesar 30,7+2,4 menjadi $43,8+1,4$ dengan nilai $p$ value sikap $0,000<0,05$ yang berarti ada perbedaan yang signifikan sikap sebelum dan sesudah dilakukan intervensi brainstorming.

\section{PEMBAHASAN}

Penelitian ini menunjukkan bahwa terdapat perbedaan pengetahuan dan sikap tentang HIV dan AIDS pada Tenaga Kerja Bongkar Muat (TKBM) di Pelabuhan Gorontalo yang signifikan sebelum dan sesudah dilakukan intervensi metode brainstorming. Metode pendidikan kesehatan melalui metode brainstorming berpengaruh signifikan dalam meningkatkan pengetahuan dan sikap tentang HIV dan AIDS pada Tenaga Kerja Bongkar Muat.

Metode curah pendapat (brainstorming) merupakan suatu teknik kreativitas yang mengupayakan pencarian penyelesaian dari suatu masalah tertentu dengan mengumpulkan gagasan secara spontan dari anggota kelompok. Hal ini sejalan dengan penelitian yang dilakukan oleh Maimun (2017) yang menunjukkan adanya perbedaan sikap pada kelompok brainstorming sebelum dan sesudah intervensi dengan hasil pengukuran skor pengetahuan dan sikap. Adanya perbedaan sikap tentang kesehatan reproduksi pada kelompok brainstorming sebelum dan sesudah intervensi dengan hasil pengukuran skor, hal ini menunjukkan bahwa adanya peningkatan skor pengetahuan dan sikap responden setelah mendapat perlakuan dari fasilitator brainstorming (Handayanidkk., 2009; Yanti., 2014;:Ratnaningsih dkk., 2015).

Metode brainstorming telah terbukti manfaatnya sebagai alat menggali informasi tentang pengetahuan dan sikap untuk mencapai tujuan. Metode ini dapat lebih dalam menggali informasi responden lebih banyak. Pelaksanaan metode brainstorming dapat dipandu oleh fasilitator yang memfasilitasi prses diskusi agar berjalan dengan lancar. Fasilitator dapat berperan sebagai narasumber bagi peserta diskusi. Seorang fasilitator harus mempunyai kemampuan untuk berkomunikasi dengan baik, mendengarkan 
pendapat setiap anggota diskusi dengan baik, menyimpulkan pendapat mereka, menggali keterangan lebih lanjut, dan mampu membuat suasana menjadi lebih akrab dan nyaman. Fasilitator juga harus menghormati sikap, pendapat dan perasaan dari setiap anggota diskusi.

Metode braisnstorming merupakan metode pendidikan kesehatan sokratik yang manamerupakan metode yang didasarkan pada cara dua arah atau two-way traffic method. Pada metode ini, baik fasilitator maupun peserta sama-sama aktif, sehingga peserta dapat aktif dan kreatif. Metode brainstorming yaitu memberikan kesempatan kepada peserta untuk mampu menampilkan kemandirian serta pengarahan diri, memiliki keterbukaan dan keutuhan diri dalam memilih alternatif tindakan yang terbaik, mampu menyampaikan pendapat dan mengaktualisasikan diri dalam memecahkan suatu masalah serta mampu menghargai pendapat orang lain. Metode brainstorming ini memberikan keleluasaan peserta untuk mengemukakan argumennya dan memecahkan suatu masalah serta mampu menghargai pendapat orang lain. Metode ini betujuan untuk mengumpulkan gagasan atau pendapat dalam rangka menentukan dan memilih berbagai pernyataan sebagai jawaban terhadap pertanyaan yang berkaitan dengan pembelajaran (Sihite, 2017).

Teori Rosenberg menyatakan bahwa pengetahuan dan sikap berhubungan secara konsisten. Bila kemampuan kognitif (pengetahuan) berubah maka akan diikuti pula dengan adanya perubahan sikap (Hutauruk, 2009). Sesuai dengan teori tersebut, terjadi peningkatan skor pengetahuan dan sikap responden pada penlitian ini setelah dilakukan intervensi baik itu metode sosilaisasi maupun metode brainstorming.

\section{KESIMPULAN}

Berdasarkan hasil penelitian yang telah dilaksanakan dapat disimpulan bahwa Ada perbedaan rata-rata nilai skor pengetahuan dan sikap sebelum dan sesudah intervensi metode brainstorming pada Tenaga Kerja Bongkar Muat (TKBM) tentang HIV dan AIDS di Pelabuhan Gorontalo sehingga metode brainstorming dapat digunakan dalam memberikan edukasi dalam meningkatkan pengatahuan dan sikap tentang HIV dan AIDS.

\section{SARAN}

Sesuai dengan observasi dilapangan, peneliti menyarankan bahwa pendidikan kesehatan tentang HIV-AIDS dengan menggunakan metode brainstorming dapat dijadikan pilihan dalam meningkatkan pengetahuan dan sikap sebagai langkah pencegahan primer, sehingga baik untuk dimasukkan dalam rekomendasi program baik kegiatan formal maupun informal.

\section{DAFTAR PUSTAKA}

Desmon, K. (2015). Epidemiologi HIV-AIDS. Bogor: In Media.

Handayani S., Emilia O.,Wahyuni B. (2009). Efektifitas Metode Diskusi Kelompok Dengan dan Tanpa Fasilitator pada Peningkatan Pengetahuan, Sikap dan Motivasi Remaja Tentang Perilaku Seks Pranikah. Berita Kedokteran Masyarakat, 25(3):133-141.

Hutauruk M.R. (2009). Hubungan Antara Pengetahuan Dengan Sikap Orang Tua Tentang Kelainan Refraksi Pada Anak (Tesis). Institutional Repository, Semarang: Universitas Diponegoro.

Kemenkes RI. (2018). Data dan Informasi - Profil Kesehatan Indonesia (Data and Information - Indonesia Health Profil). Jakarta: Kementrian Kesehatan Republik Indonesia.

Maimun D.N., Dupai.L., Erawan P.E. (2017). Pengaruh Kesmas Cilik Dalam Meningkatkan Pengetahuan, Sikap dan Tindakan Perilaku Hidup Bersih dan Sehat Murid Kelas V Sekolah Dasar Negeri Poasia Kota Kendari. Jurnal IImiah Mahasiswa Kesehatan Masyarakat, 2(5)1-9.

Mardalina A. (2015). Faktor-Faktor yang Berhubungan dengan Perilaku Seks Berisiko HIVIAIDS pada Tenaga Kerja Bongkar Muat (TKBM) di Pelabuhan Tanjung Emas Semarang. Jurnal Kesehatan Masyarakat, 3(3):869-876.

Margawati K. \& Hargono A. (2017). Perilaku seksual berisiko penularan HIVIAIDS pada tenaga kerja bongkar muat di pelabuhan kalimas surabaya. Jurnal Promosi dan Pendidikan Kesehatan Indonesia, 3(2):183194.

Ratnaningsih. M., Zulkifli. A., Hakim. B.A. (2015). Pengaruh metode simulasi permainan dan brainstorming terhadap pengetahuan dan sikap Pengurus PIK-R SMA tentang kesehatan reproduksi remaja di kota makassar (Tesis). Fakultas Kesehatan Masyarakat. Makassar: Universitas Hasanuddin. 
Sihite P. dkk. (2017). Pengaruh Edukasi Kesehatan Reproduksi Terhadap Pengetahuan Siswa Tentang TRIAD KRR (Seksualitas, HIVIAIDS, dan NAPZA) di SMK Swadaya Kota Semarang. Jurnal Kesehatan Masyarakat, 5(4)237-246.

Yanti S.D. dkk. (2014). Hubungan Pengetahuan remaja Puteri Tentang Menstruasi Terhadap Perilaku Higienis Pada Saat Menstruasi . Jurnal Psikologi, 1(2):1-8 